1 Wells CG, Gutfreund $M$. The conversational requirements for language learning. In: Yule $W$ Rutter M, eds. Language development and disorders. Oxford: Mackeith Press, Blackwell Scientific Publications, 1987: 90-102. (Clinics in Developmental Medicine 101/102.)

2 Rutter M. Assessment of language disorders. In: Yule W, Rutter M, eds. Language development and disorders. Oxford: Mackeith Press, Blackwell Scientific Publications, 1987:295-311. (Clinics in Developmental Medicine 101/102.)

3 Bishop DVM. The concept of comprehension in language disorder. In: Martin JAM, Fletcher P Grunwell P, Hall DMB, eds. Proceedings of the first international symposium on specific speech and language disorders in children. London: Association for All Speech Impaired Children (AFASIC), 1987:75-81

4 Conti-Ramsden G. Mother-child talk with language-impaired children. In: Martin JAM, Fletcher P, Grunwell P, Hall DMB, eds. Proceedings of the first international symposium on specific speech and language disorders in children. London: Association for All Speech Impaired Children (AFASIC), language disorit $1987: 276-83$

5 Tallal $P$. The neuropsychology of developmental language disorders. In: Martin JAM, Fletcher P Grunwell $\mathrm{P}$, Hall DMB, eds. Proceedings of the first international symposium on specific speech and language disorders in children. London: Association for All Speech Impaired Children (AFASIC), language disorde

6 Robinson RJ. The causes of language disorder. In: Martin JAM, Fletcher P, Grunwell P, Hall DMB, eds. Proceedings of the fint international symposium on specific speech and language disorders in children. London: Association for All Speech Impaired Children (AFASIC), 1987:1-19.

7 Gordon N. Developmental disorders of speech and language. In: Yule W, Rutter M, eds. Language development and disorders. Oxford: Mackeith Press, Blackwell Scientific Publications, 1987:189205. (Clinics in Developmental Medicine 101/102.)

8 Rapin I. Developmental dysphasia and autism in pre-school children; characteristics and subtypes. In: Martin JAM, Fletcher P, Grunwell P, Hall DMB, eds. Proceedings of the first international symposium on specific and language disorders in children. London: Association for All Speech (AFASIC), 1987:20-35.

Miller JF. A grammatical characterization of language disorder. In: Martin JAM, Fletcher $P$, Grunwell P, Hall DMB, eds. Proceedings of the first international symposium on specific speech and language disorders in children. London: Association for All Speech Impaired Children (AFASIC), 1987: 100-13.

10 Berger $M$. What is a language disorder? In: Martin JAM, Fletcher P, Grunwell P, Hall DMB, eds. Proceedings of the first international symposium on specific speech and language disorders in children. London: Association for All Speech Impaired Children (AFASIC), 1987:61-74.

11 Snyder-McLean L, McLean JE. Effectiveness of early intervention for children with language and communication disorders. In: Guralnick MJ, Bennett FC, eds. The effectiveness of early intervention for at-risk and handicapped children. Orlando, Florida: Academic, 1987:213-74.

12 Gruenewald $\mathrm{LJ}$. Language intervention in integrated public school settings. In: Martin JAM, Fletcher P, Grunwell P, Hall DWB, eds. Proceedings of the frost imsormal symposium on specific Fletcher $P$, Gri speech and language disorders

13 Yule W, Udwin $O$. The role and value of augmented communication. In: Martin JAM, Fletcher $P$, Grunwell P, Hall DMB, eds. Proceedings of the first international symposium on specific speech and language disorders in children. London: Association for All Speech Impaired Children (AFASIC), language disorders

14 Prinz PM. Current issues on sign language as an augmentative/alternative form of communication for speech/language impaired children. In: Martin JAM, Fletcher P, Grunwell P, Hall DMB, eds. Proceedings of the first international symposium on specific speech and language disorders in children. London: Association for All Speech Impaired Children (AFASIC), 1987:353-66.

15 Silva PA. Epidemiology, longitudinal course, and some associated factors: an update. In: Yule W, Rutter M, eds. Language development and disorders. Oxford: Mackeith Press, Blackwell Scientific Publications, 1987:1-15. (Clinics in Developmental Medicine 101/102.)

\title{
Impact of changes in social security
}

\section{Insufficient research}

In the spring of this year Britain's social security system was radically changed. The government aimed at simplifying the system, encouraging people to seek jobs, and reducing public spending. But what will be the effects of the changes? The answer to this question is crucial because an efficient social security system is vital for reducing the inequalities in health that are such a deep seated problem in Britain. ${ }^{12}$ Yet the government has been parsimonious in sponsoring research into this multibillion pound reform.

In the new system supplementary benefit has been abolished. It was paid to those living below what the government of the day deemed to be a minimum acceptable income for those not in full time work. It has been replaced by income support, comprising a basic allowance, a dependant's allowance for children, and premiums for special groups such as the disabled, pensioners, or one parent families. Family income supplement, previously paid to families with children whose breadwinner was in low paid work, has been replaced by family credit. Most contentiously, single payments to those receiving supplementary benefit-say, for a cooker or a hospital visit - have been replaced by the social fund. This fund is cash limited and provides loans rather than grants while payments are given at the discretion of a fund officer. Finally, housing benefit remains for those on income support, but one million people may lose entitlement and a further five million may experience a reduction.

Problems have already been reported with the new system..$^{45}$ For example, local authorities have noted a steep rise in rent arrears because of cuts in housing benefit. Organisations such as the Child Poverty Action Group claim that the poor are being made poorer; it points to such factors as the reduced benefit payable to those under 25 . It is alarmed that the "premium" part of income supplement reintroduces the concept of a "deserving" and "undeserving" poor (see box). ${ }^{3}$ The greatest anxiety concerns the social fund. Reports from offices of the Department of Social Security suggest that requests for help are much lower than expected. It is hardly surprising if the very poor are reluctant to take on a loan, even at favourable rates.

Clearly many of the objections to the new system are not accepted by the government, but we must find our way

Effect of sociál security changes on an unemployed family with two preschool children ${ }^{3}$

Income under old system ( $£$ a week) Income under new system ( $£$ a week)

50.95 Couple

21.50 Children

4.40 Heating addition

4.15 Average single payment

81.00 Total

This couple could seek help from the social fund if, for instance, their children need new shoes. But the payment would be a loan, and half of those entitled to means tested benefits do not claim.

through the fog of political argument and discover what is really happening. Funding for social science research has diminished over the past five years, but the last minister promised his intention to start projects in the spring of 1989after the necessary "settling down" period."

We need to know whether the new system is genuinely simpler or whether it leads to rough justice. Does the introduction of flat level premiums within income support truly reduce the need for exceptional payments? Already this is so doubtful that complex transitional arrangements have been made to tide over the biggest losers. Pensioners who have lost out seriously on housing benefit are protected, but if there is a change in their circumstances-for example, a spell in hospital - they may lose that protection.

The Department of Social Security is expected to undertake a small scale trial to evaluate family credit and is likely to look at local variations in take up of the social fund. It should also consider whether the act has solved the conundrum of the unemployment trap. Under the new rules claimants who are unemployed lose income support when they find a job, but if the work is low paid they may receive family credit so that they are no worse off. But what about childless couples who are not entitled to family credit?

The reforms aim to redirect benefit to families with children and away from other groups such as pensioners. ${ }^{78}$ But the increase in benefit for families may be more than offset 
by the lower take up of single payments. As one way of financing these benefits has been by not increasing child benefits for non-claimants in line with inflation the result may be merely that the poorest children do a little better at the expense of other children. This is important because there is no doubt that families with children have faced a steeper increase in poverty than others. For example, in 1985, $2 \cdot 25$ million children ( $18 \%$ of the total) were living at or below the poverty line,$^{3}$ an increase of $91 \%$ on the figure at the time of the Black report. ${ }^{1}$

The first target for Europe of the World Health Organisation's plan for health for all in the year 2000 is to reduce inequalities in health by a quarter. ${ }^{9}$ The organisation has called for a research policy to back up its targets, and research into health inequalities should aim at understanding the mechanisms that create and maintain the inequalities. ${ }^{10-12}$ This will demand research into the impact on poverty and health of social security policies. The Department of Health and Social Security has now been split into two departments. Social security has a larger budget than health but commissions far less research. The new Department of Social Security should surely be provided with a research budget that will allow it to discover whether what the government's critics say is true - that "over the past decade growing abundance for some has been accompanied by persistent poverty and

hardship for a significant minority. ${ }^{13}$ Or whether a more accurate statement is the one made by the Prime Minister when she told the House of Commons that "Everyone in the nation has benefited from the increased prosperityeveryone."

HARVEY MARCOVITCH

Consuitant Paediatrician,

Horton General Hospital,

Banbury,

Oxfordshire OX16 9AL

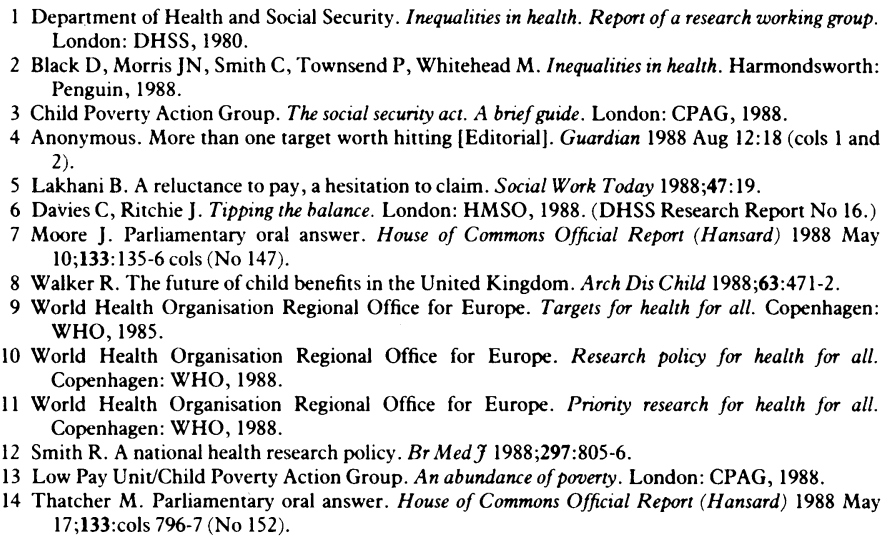

\section{Germ cell tumours in men}

\section{Diagnosis of these cancers is often delayed}

More than three quarters of men with germ cell tumours may now be cured with chemotherapy containing cisplatin. ${ }^{1}$ Yet diagnosis is often delayed, sometimes with dire consequences. ${ }^{2}$

In 1984 there were 909 cases of testicular cancer in England and Wales, ${ }^{3}$ representing at least an increase of a half in the past 20 years. The reasons for the increase are uncertain, ${ }^{+}$but this is by far the commonest malignancy in men aged 20-34and the incidence is continuing to rise rapidly. The public know little about the disease, which is one reason for delayed diagnosis.'

In most patients diagnosis is straightforward. Usually the patient draws attention to an abnormal testis which may be painful with an area of induration or a mass. Occasional patients present with a hydrocele or a mass noted immediately after trauma to the testicle. Testicular neoplasms should always be considered in such cases, and the patient should be referred to a urologist.

Although testicular seminoma is commonly confined to the testis, metastases are present in at least half of all patients with teratoma. In many of these cases the presenting symptoms result from the metastases. A palpable testicular mass may be small, absent, or concealed by an embarrassed patient. Patients then present with symptoms caused by metastatic disease. Lumbar back pain, ${ }^{2}$ which is often progressive and poorly controlled, and abdominal pain may be caused by cancer spreading to retroperitoneal lymph nodes. Progression of the disease may cause leg and genital oedema secondary to compression of the inferior vena cava, compression of the spinal cord, or obstruction of the ureters or small bowel. ${ }^{6}$ Occasional patients notice an abdominal mass. Lung metastases are common, but they rarely cause symptoms. Patients may, however, present with cough, dyspnoea, chest pain, or haemoptysis. Patients with large mediastinal masses may present with dyspnoea, obstruction of the superior vena cava, or occasionally pericardial tamponade. ${ }^{7}$ Some patients present with cervical adenopathy: the nodes are usually confined to the supraclavicular fossa or scalene area on the left, and the masses may occasionally be large. Occasional patients present with metastases in the central nervous system, liver, or bone, but such patients almost always have readily apparent metastatic disease at other sites, particularly in the chest. Finally, gynaecomastia in a young man in association with a testicular mass or lung metastases is virtually pathognomic of a metastatic germ cell tumour.

Young men presenting with any of these symptoms should have a full genital examination. If this gives normal results and there is any suspicion of a germ cell tumour then the testes should be examined with ultrasonography to exclude an impalpable primary tumour. In some patients $(10 \%$ in Southampton) there is no tumour in the testes; these patients have the extragonadal germ cell syndrome and may present with retroperitoneal or mediastinal masses ${ }^{89}$ or with lung metastases. In most patients the serum concentrations of $\alpha$ fetoprotein or the $\beta$ subunit of human chorionic gonadotrophin are high, and large increases are common. When possible the diagnosis should be proved in such patients by biopsy. Biopsy of tumours with prominent elements of choriocarcinoma may, however, be dangerous because of haemorrhage.

Pathologists should be alert to the possibility of a germ cell tumour in any specimen of metastatic neoplasm obtained from a young man. Diagnosis may be difficult and histology atypical. In the absence of an obvious primary site, patients with a final diagnosis of poorly differentiated carcinoma (even in the presence of normal serum markers) may still be considered for treatment with cisplatin containing 